\title{
Aunty and Her Little Villains. The BBC and the Unions, 1969-1984
}

\author{
Anthony McNicholas
}

\author{
CAMRI, University of Westminster, London, UK. \\ http://www.westminster.ac.uk/about-us/our-people/directory/mcnicholas-anthony \\ mcnichc@westminster.ac.uk
}

\begin{abstract}
This article charts industrial relations in BBC television from 1969-84. It is based upon extensive archival research of material not previously available, and witness seminars and interviews with some of the protagonists. This was a period which saw a rise in industrial militancy at the BBC, signalled by the first "lightning" strikes in the BBC's history in 1969 and ending with a strike in the scenic services department in 1984, in the course of which BBC TV went off the air for twenty four hours but BBC management reasserted its control. In the intervening period, some groups of workers were able to secure advantageous terms and conditions for themselves, to the frustration of both management and the main BBC union, the Association of Broadcasting Staff (ABS). This article offers a detailed and nuanced analysis of industrial relations at an important British cultural institution in a turbulent period of its history.
\end{abstract}

Keywords: BBC, Unions, Industrial Relations, Nineteen Seventies, Militancy, Strikes, Union Mergers, Pay Policies

Acknowledgement: This research was supported by the Arts and Humanities Research Council, and the BBC. Especial thanks are due to the staff at the BBC Written Archives Centre, Caversham and to all those former BBC employees and union officials who agreed to be interviewed and to Professor Jean Seaton, University of Westminster for her guidance and friendship.

\section{Introduction}

This article is a discussion of industrial relations at the BBC from the early nineteen seventies to the mid-1980s. This was a turbulent period in the history of the BBC: inflation and changing political opinion was putting the licence fee, the foundation of the BBC's independence under pressure; in the country, coverage of social and industrial unrest, continuing political violence in Northern Ireland and the conflict in the Falklands all lead to tensions with government. There was competition with the better-funded commercial broadcasters for staff. It was also a time when the balance of power between unions and management was in a state of flux; from the late nineteen sixties onwards the unions seemed to be gaining the upper hand but towards the end of the period under discussion, the scales tipped decisively in favour of management. It is "bookended" by two events: the lightning strikes in Television Centre in 1969 - the first in the BBC's history - and the scenic services dispute of 1984, which took place over six weeks in the spring of 1984 and saw the BBC sacking over 600 of its employees and the unprecedented closedown for 24 hours of BBC television. In this account of fifteen years of varying degrees of industrial strife, it aims to do two things: to give a picture of labour relations in a major broadcaster, an area of industry which has not received much academic attention and also to add new material to general accounts of the period, with a view to providing some colour to a scene which is often painted in rather stark terms.

A pervasive view of the industrial relations of the time sees a Manichean struggle between an embattled British industry and militant trade unionism. In this view, common to both much of the journalism and political discourse of the time, and of the received wisdom ever since, the UK was a country held to ransom by both official and unofficial strikes; its productivity undermined by demarcation disputes, restrictive practices, unreasonable wage demands and luddite responses to new technology. According to this perspective, Britain was in seemingly 
terminal decline, as governments had been unable or unwilling to confront organised labour, until the administration of Mrs. Thatcher grasped the nettle and finally sorted out the mess. The new industrial relations environment resulting from the election of the Conservatives in 1979 , saw the trade union movement, from a position at the centre of government policy under the previous Labour administrations, immediately expelled into the outer darkness (Crouch 1990, 332). and fall so far from sight, that it has been noted that in the memoirs of Lord Young, first Secretary of State for Employment from 1985-7, and then of Trade and Industry from 1987-9, "the words trade union do not appear in the index" (Taylor 1993, 302).

What happened at the BBC, inevitably, is somewhat more complex. From this article, based upon unfettered access to internal documentation not previously seen and still not generally available, and personal interviews and witness seminars with those involved, a different picture emerges. Industrial relations at the BBC, traditionally based upon a Reithianinspired sense of loyalty to the corporation and an identification with its purposes, encompassing staff at all levels had historically been good and were even in this period carried on (mostly) in an atmosphere of mutual respect. The corporation did, like many other institutions at this time experience unprecedented levels of industrial strife. The causes are many and complex. In broadcasting, the coming of independent television in 1955 had made an industry of what had belonged to one institution and staff in the BBC could now compare pay and conditions in a way they could not before. Economies the world over struggled with the effects of the rising price of oil. There was also a national industrial context and "The period 1968-74 witnessed the biggest strike wave in Britain for half a century" (Lyddon 1999, 326), culminating in the iconic Winter of Discontent of 1978-9. The economic and political exigencies of the 1970s led to a situation where prior arrangements, relationships, and systems simply no longer worked, leading to a period of instability and conflict.

The argument is developed over the following sections which follow: first is a discussion of the theoretical and political background to the events analysed and some remarks on the methodology employed and the writing of media history; the following three sections outline the ecology of union membership at the BBC, discuss the growing union militancy in the corporation set against government industrial policies, especially on pay; of; and political background against which it occurred; the four following sections deal with the 1984 strike with which the narrative closes by describing the working arrangements on the affected section of the $\mathrm{BBC}$, changing management attitudes to industrial relations, and an account of the particular dispute and how it unfolded. The article concludes with discussion of how the dispute was seen at the time.

\section{Industrial Relations, Media History, Neoliberalism and the End of the Keynesian Compromise}

This article is concerned with industrial relations. This term is one that has in recent years come under question in the academy. Some scholars have argued that as trade unionism in advanced capitalist societies has itself declined, the subject needs to be redefined to reflect this new reality (Kaufman 2008, 32). This is in part a consequence of the kind of events here under discussion. Therefore, as the period dealt with predates this decline, I use the term in the sense that was until recently the norm, i.e. the study of trade unions, collective bargaining, labour-management relations, and relevant law and policy (Kaufman 2008, 31). I include also the question of relations between different trade unions.

This is also not a work of media theory, but rather of media history. It is therefore necessary to justify its presence in the pages of a journal generally given over to theoretical approaches. Media history has a long pedigree. James Curran has claimed that it was within the discipline of history that serious study of the media began, a position of prominence from which he writes media history has sadly fallen and is now "the neglected grandparent of media studies: isolated, ignored, rarely visited by her offspring" (Curran 2002, 3). The present author is then one of the faithful grandchildren. Broadly speaking, the purpose of the historian is to attempt to answer questions on the basis of the interpretation of evidence about the actions of people in the past in order to enhance our self knowledge (Collingwood 1994, 10), 
or as this has been interpreted, to gain an understanding of the past "as a key to the understanding of the present" (Carr 1990, 26) and the writing of history is "a continuous process of interaction between the historian and his [or her] facts, an unending dialogue between present and past" (Carr 1990, 30). A historicist approach is a cultural necessity, "it is a precondition of critical social thought about the present and the future" (Tosh 2002, 197). As Nicholas Garnham has put it, "evidence drawn from history, even if it is from the very recent past, is the only evidence we have against which to test sociological theories" (Garnham 2000, 17). The evidence adduced here is of two kinds - an examination of the internal documentation of the BBC, and interviews and witness seminars with key personnel. The documentation, minutes of meetings, position papers etc., comes from the BBC's written archives. The author was part of a team working on the official history of the BBC 1975-87. Being part of such a project has implications for the type of access afforded to the researcher. The BBC generally allows access to its internal records on the same basis as government departments and employs a 30-year rule. This means in effect that no papers under 30 years old will be made available for researchers to consult. Currently, the BBC cut-off date is 1979. Files are also vetted and sensitive material removed. As part of an official team, no such restrictions applied - all files were made available to the team and nothing was redacted. Interviews and witness seminars were also carried out. Professional historians have mistrusted so-called "oral" sources of history, viewing them as being tainted by hindsight and also perhaps because historians see themselves as being the interpreters of rather than the creators of new evidence (Tosh 2002, 297). Witness seminars are a technique developed in the Institute of Contemporary British History where people involved in an event or circumstance are brought together by historians to discuss their reminiscences. This work is the result of comparisons between and analysis of the written records, the oral testimony, published accounts of the events described.

Those events took place at a time of profound economic, social and ideological change, in the UK and in the Western world generally. The industrial action at the BBC in 1969 took place on the cusp of a decisive break with the recent past. By this time post-war economic growth had begun to falter, to be replaced by high inflation and growing unemployment. The previous thirty years or so had seen governments in advanced capitalist countries willing to intervene in markets, to pursue a degree of redistribution of wealth, and to create some welfare provision for their citizens. This was the post war or Keynesian consensus, which included even presidents of the USA, Richard Nixon being quoted as saying "We are all Keynesians now" (Harvey 2005, 13). As economies began to fail, so economic ideas, which had hitherto found few admirers came to the fore, prominent amongst them the monetarist theories of Milton Friedman and those of Friedrich Hayek. Neoliberalism as this new economic and political doctrine is generally known has spread from its origins in the UK under premier Margaret Thatcher, in Ronald Reagan's USA, and in the China of Deng Xiaoping, "to remake the world around us in a totally different image". It has become "the central guiding principle of economic thought and management" (Harvey 2005, 1-2).

Neoliberalism, a "long term tendency and not [...] a teleological destination" (Hall 2011, 708), is mutable, differently inflected according to time and location, and in the UK associated with or synonymous to Thatcherism. It "straddles a wide range of social, political and economic phenomena" (Saad-Filho and Johnston 2005, 1). It represented the overturning of three key elements of the "Keynesian compromise" which characterized most Western economies in the period following the second world war: control of capital; government intervention in the operations of markets; and social and welfare policies (Campbell 2005, 189). Some writers have argued that elites saw their interests threatened especially by the redistributive tendencies in the years that Keynesian policies held sway, and for them neoliberalism, which was not so much "the ideology of the market and private interests as opposed to state intervention" but "fundamentally a new social order in which the power and income of the upper fractions of the ruling classes - the wealthiest persons - was reestablished in the wake of a setback" (Duménil and Lévy 2005, 9). Harvey concurs, writing that neoliberalism is more than anything else "a political project to re-establish the conditions for capital accumulation and to restore the power of economic elites" (Harvey 2005, 19). 
In the UK, "the Thatcher revolution", was particularly influenced by neoliberal theory, more so than the US was under Reagan (Harvey 2005, 62), but she did not introduce monetarism. The Labour government of James Callaghan had been forced to turn to the IMF in 1976 to bail out the flagging UK economy and under pressure from the IMF, began putting in place deflationary policies, which provoked the industrial unrest of the so-called Winter of Discontent of 1978-9 (Evans 2004, 11-12). The consequences of this disruption, generally in the public services, gave the Conservatives enough support in the country to tackle the unions head on. Trade unions came first in the list of institutions, which were to be confronted by the incoming Conservative government, followed by municipal governments, various professional interest groups, and all facets of the welfare state so painstakingly built up in the years of the post war consensus. The set-piece confrontations were with the major industrial unions in coal, steel and the railways. The Tories prepared carefully for their battle with the miners, stockpiling coal in order to reduce the effects of an all-out stoppage. Cabinet papers recently released show that the head of Mrs Thatcher's policy unit, wrote in a confidential memo, "We must neglect no opportunity to erode trade union membership wherever this corresponds to the wishes of the workforce. We must see to it our new legal structure discourages trade union membership of the new industries" (Travis 2013).

In their three administrations from 1979 the conservatives set about destroying the power of trade unions in British industrial and political life with a succession of acts. The Employment Act 1980 outlawed secondary picketing and restricted the closed shop. These were measures which some in the conservative party thought did not go far enough. It was to be but the opening shot in a long, unequal war between the forces of the state and organised labour. The 1982 Employment Act tightened the definitions of what constituted a lawful strike, prevented industrial action taken in sympathy with other sets of workers and further restricted the closed shop. 1984 saw the Trade Union Act, which required postal ballots of union officials. Legislation in 1988 took away union immunity from claims for damages arising out of industrial action unless secret ballots had been held beforehand. As Chris Wrigley, a historian of trade unionism has put it,

The legislation of the early 1980 s tended to tilt the balance in industrial relations back in favour of the employers, and so moving against the strengthened trade union role of 1974-9 [...] After the bitter year-long miner's strike of 1984-5, the legislation took matters much further in an anti-trade union direction (Wrigley 1997, 161).

In its own terms, the legislation and accompanying coercion by the state was successful; trade union membership, 13.5 million in 1979, fell to below 10 million by the time Mrs Thatcher left office just over a decade later (Evans 2004, 40) and has continued to fall.

This is the background against which the events at the BBC between 1969 and 1984 took place. The legislation mentioned above was not decisive in the struggles between unions and management in the early to mid 1980s - but the it was clear the world had changed and if ever management were to challenge trade union power, that time was after 1979.

\section{Rows, Courtships and Marriages: The BBC Unions}

It is unsurprising that a large and complicated organization like the BBC with a wide range of skills and occupations should have a correspondingly complex set of arrangements on the union side. The main union at the BBC was the ABS (the Association of Broadcasting Staff). It was recognised by the BBC across all areas. Other unions obtained recognition over the years for certain occupations: the NUJ (National Union of Journalists) for example in news; NATTKE (National Association of Theatrical Television and Kine Employees) mainly in the scenery department; and the EETPU (Electrical Electronic Telecommunications and Plumbing Union) organized some of the electricians. Some ABS members were also members of other recognised, or in some cases, unrecognised unions such as the ACTT (Association of Cinematograph Television and Allied Trades), which represented technicians in the commercial sector. The story of inter-union relations at the BBC began as one of rivalry for members, 
as the various unions sought recognition but as the industrial climate turned against them, it became one of amalgamations (see figure 1, below).

Industrial relations in the BBC had historically been much better than in the ITV companies. There was no BBC equivalent to the strike and lock out of 1979, which saw commercial television off the air for ten weeks. There was no closed shop agreement, which weakened the ABS, and it never enjoyed the same leverage with management as its counterparts in commercial television. Twice, in 1968 and again in 1975, the ABS had tried unsuccessfully to persuade the BBC to allow a closed shop with it in order to resist encroachments from the ACTT,(G48/75 "The Closed Shop: Note by the Director of Personnel" 28/2/75, BBC Written Archives Centre, Caversham, hereafter BBCWAC), but the corporation had refused, viewing a closed-shop as incompatible with editorial freedom, and had told the unions, that on this, they were prepared to go off air for an indefinite period rather than concede (G244/76 "The Closed Shop: Note by Director of Personnel" 28/10/76, BBCWAC).

1890

United Kingdom

Theatrical and Music

Hall Operatives Union

1901

National Un-

ion of Theatrical

Stage

Emplovees

1904

National Associa-

tion of Theatrical

Employees

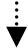

1936

National Associa-

tion of Theatrical and

Kine Employees

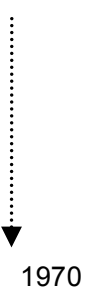

National Association of Theatrical Television and Kine Employees
Contributors Unions

1893 Musicians Union

1907 National Union of Journalists

1930 Equity

1958 Writer"s Guild
1933

Association of

Cinematograph

Technicians

BBC Staff

Association

1956

Association of

Broadcasting Staff

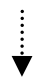

1974

Associa-

tion of Broad-

casting and

Allied Staffs

1984

Entertain-

ment Trades

Alliance

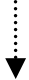

1985

Broadcasting

and Entertainmen

Trades Alliance

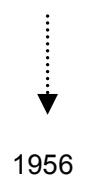

Association of Cinematograph Television and Allied Technicians

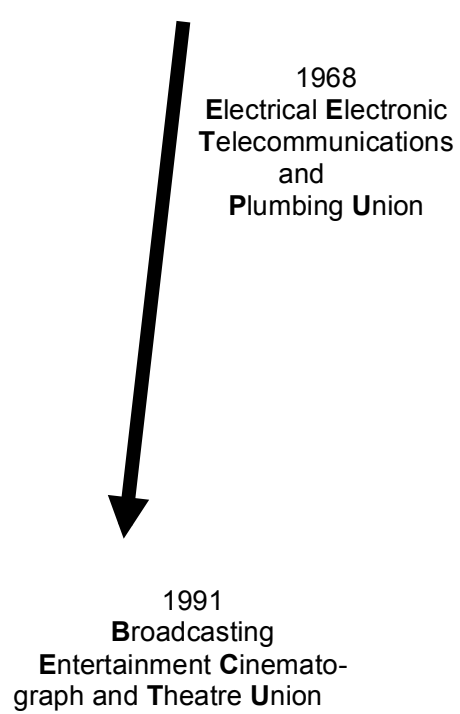

Figure 1. The BBC unions 
BBC funding also limited the unions' room for manoeuver. That the government decided the level of the licence fee meant that the BBC had no control over its revenue and for the unions it meant that they could not interrupt the flow of that income by industrial action. The size and diversity of the BBC also meant that staff had opportunities for transfer and advancement unavailable in the commercial broadcasters, which even taken together were much smaller than the BBC. This meant there was much less for the ABS to strive for, "In short, the aspirations and ambitions of BBC staff could find expression in the Corporation whilst in commercial television they came to be expressed through the union" (Seglow 1978, 209-211). All of this left the ABS weak and survival had been the central concern for most of its history. It had begun during WW2 as a staff association, and had only become a genuine trade union nearly ten years later in 1954, finally affiliating to the Trade Union Congress (TUC) in 1963. The ABS was an unlikely vehicle for militancy and support in the BBC for union membership had always been lukewarm. When staff were first canvassed about the idea of an association in 1935, "Eighty percent were opposed to the idea" (Burns 1977, 60) and subsequent recruitment to the association, "barely kept pace with the increasing size of the BBC" (Seglow 1978, 212).

According to Tony Hearn, the long-serving General Secretary, when he joined the ABS in 1955, it was the weakest of the three broadcasting unions, after the ACTT and NATTKE, and had the ACTT been able to win recognition, his union would have been lost (Tony Hearn interview, 13/6/2003). Though not recognized by the BBC, the ACTT still formed part of the industrial relations ecology; unions outside of official agreements also influenced what was going on inside. The ACTT operated in a world, which was much less genteel than the BBC and it had a fierce reputation, even among fellow trade unionists. One NATTKE official was quoted as saying it was, "like a useful but savage beast: every so often you let it loose to bite the employer, and then you chain it up again" (Last 1979). Relations with the ABS were not always good; in return for the ABS opposing ACTT attempts at gaining recognition in the $B B C$, the ACTT had objected to the ABS affiliating to the TUC. It did, however, accept members from the $B B C$ as a way of bolstering its claims for recognition and anyone inside the $\mathrm{BBC}$ who thought that one day they might want to work in the commercial sector, had to get an ACTT ticket.

As the nineteen seventies progressed, rivalry turned to talks about alliances and the scramble for members turned into mergers. ACTT members rejected overtures from the ABS in 1978, which then went on to merge with NATTKE in 1984 on the "rebound", to form the ETA, (Entertainment Trades Alliance, adding "Broadcasting" to its title the following year). In the late nineteen seventies, the ACTT, representing highly skilled technicians, was still able to pursue a "guildist" policy as a union, but the position was changing: new broadcast technology was becoming more user-friendly, and correspondingly less dependent on skilled technicians; conservative legislation outlawed the closed shop and severely restricted the tactics which unions could employ; and structural changes in the industry led to an increasing casualization of the workforce (Campling and Mitchelson 1997, 217-222). The current broadcasting union, BECTU (Broadcasting, Entertainment, Cinematograph and Theatre Union) was created with the merger of BETA and the ACTT in 1991. In the British industrial scene, some mergers were more in the character of takeovers by a small number of large unions (Undy 1999) but this was not the case at the BBC nor in broadcasting generally. This final merger, like the ABS/NATTKE one which preceded it was, in the words of Tony Hearn not a matter of one union swallowing another, not "imperialism," but more "three unions under fire, in retreat from a hostile government, trying to form a defensive grouping" (Interview, 13/6/2003).

\section{1969 and All That: Militancy, Grading and Conditions of Service}

Tom Burns in his study of the inner workings of the BBC discerned what might be called "cultural" changes in the corporation between his first set of interviews with staff members in 1963 and his second ten years later. In 1973 people talked about working "for" the BBC when before they had worked "in" it, and were much more disgruntled than they had been. 
The BBC had in the intervening period become "industrialised" (Burns 1977, 211-14). It was now managed, rather than administered and it began to suffer from industrial troubles. And if only some $60 \%$ of staff were unionised, they were concentrated at "pinch-points" in the system, close to production, where any stoppage would cause disruption. Militancy occurred, logically enough, where it would have an effect.

A significant number of disputes were over conditions of service. The conditions of service current in the mid-1980s had been largely established in 1970. The 1970 changes, which applied the fruit of two years of discussion with the unions, attempted to compensate staff who worked outside of what were considered "social hours" (i.e. 9.30-5.30) by supplementary payments on top of basic salary. Applying to "OP" grades, as they were known, (manual and some technical staff), they were announced at the time as "one of the most complex productivity negotiations" ever in the UK and were to amongst other things, achieve reductions in staff numbers, overtime, demarcation disputes, enhance flexibility and match manning to actual requirements (R78/408/1 Manual Staff Productivity Agreement part 2 Press release 13/5/70, BBCWAC).

The 1970 reforms had also come in response to a new and alarming union militancy, which though bubbling away under the surface since at least 1965 (Seglow 1978, 213) first manifested itself on Saturday, October $11^{\text {th }} 1969$. In pursuance of a pay claim, and against the background of the ongoing talks on conditions of service, ABS members simply walked out without warning. In the studios, the effects were dramatic. The ABS had notified the BBC it had intended to take twenty four-hour-action, but had neither specified the form it would take, nor the precise date. It is difficult now to recognize the sense of shock felt by those affected. In one studio, senior Light Entertainment producer Yvonne Littlewood, could only console a tearful singer Petula Clark, after the crew did not return from dinner, leaving themselves, the orchestra and the audience literally in the dark. The action was well supported where it counted, only 15 studio staff out of 220 on the rota had worked and the studios had virtually come to a standstill (R2/1/45 BOM 13/10/69 718 "Relations with the ABS", BBCWAC). Roger Chase, then Deputy Director of television personnel said, "It is impossible to exaggerate the significance of this [event] to the whole television service, from top to bottom". What it represented, to the management, was the transformation of the ABS, "It was one of those moments when it became obvious we had an industrial union". To lose programmes was at the time unthinkable; BBC management was imbued with the ethos, "the show must go on" at all costs, and subsequently, for many years management tended to give in "with greater facility than might have otherwise been the case" (Seminar University of Westminster, 16/10/2003). This came from the very top, and it is instructive to see the reaction of Director General Charles Curran, to what became a month-long campaign of "guerrilla action" by ABS members. The dispute had been sharpest in those areas where the workforce had industrial muscle - in television - and management was well aware that this would remain the case in future. Curran told a Board of Management meeting at the end of the month, that as they had been and expected to be exposed in the television service,

so it became essential to ensure that the conditions of service settlement when finally achieved was such as to meet the reasonable aspirations of Television Service staff, even if it meant that other Directorates had to suffer financially as a result [my italics] (R2/1/45 BOM 27/10/1969 741, BBCWAC).

This was precisely what was to happen in the coming years, as to the growing frustration in BBC management, in less powerful sections of the workforce and the ABS leadership, staff in areas close to production were able to extract favourable conditions for themselves. In the meantime, relations between the BBC and the ABS, which had historically been amicable tended to get worse "in spite of everybody's best efforts, I mean nobody wanted it to get worse, but it tended to get worse" (R. Chase, seminar).

In practice, then, the effects of the 1970 changes created various disparities, between different groups of workers, some of whom qualified for the new enhanced payments and some of whom did not. Supervisors and managers ("MP" grades) complained that the new ar- 
rangements did not take sufficiently into account rewards for skill and responsibility and that for working the same hours, they often earned less than the people whom they supervised. As early as October 1970, when the new arrangements were only a few months old, the weekly News and Current Affairs meeting was told that a cameraman on a recent assignment to Amman in Jordan, had earned through extra payments, two or three times as much as the two reporters who accompanied him. Fears were expressed that unless something was done, reporters would in the end refuse to work beyond their official hours and thus scupper the entire news operation (R78/405/1 Conditions of Service Policy Non-manual staff part $1 \mathrm{~N} \& C A$ meeting 2/10/70, BBCWAC). By the following February it was estimated that some cameramen could earn more than not only their own supervisors but the Head of Filmic Operations (R78/405/1 Conditions of Service Policy Non-manual staff part 1 Note "Conditions of Service" CR East 6/8/71, BBCWAC). By October 1971, in an exchange of memos between senior managers in personnel, it was noted some of the staff concerned were themselves "astonished" at the amounts they were earning, and that though some people were suggesting they should try to renegotiate the conditions of service, the Controller of Personnel in television Leslie Page considered this not "a practical proposal to put to any union", and the Director, MO Tinniswood, further noted that "anything other than the gentlest distortion in present relativities" would be "unpalatable" to the ABS, whose greatest strength lay in those OP grades who had benefited from the 1970 arrangements (R78/405/1 Conditions of Service Policy Non-manual staff part 1 Note 14/10/71 CL Page to MO Tinniswood and 21/10/71 MO Tinniswood to CL Page, BBCWAC). It had been intended, within one overarching national framework to cope with the complexities of modern broadcasting. However, in addition to the weaknesses apparent from the outset, the 1970 conditions of service had to cope with changing conditions, from new technology and extended broadcasting hours, to the distorting effects of government curbs on pay.

\section{Living in a Burning House: Pay Policies, Evasions and Grading}

For what took place at the BBC did so in the context of government policy. Both Conservative and Labour governments used pay policies in their efforts to combat what was the most pressing economic problem of the period, namely inflation. Incomes policies were however, far from perfect as instruments of financial control - they were, even to those who formulated them, acts of desperation. As Labour Chancellor Dennis Healey was himself to admit,

Adopting a pay policy is rather like jumping out of a second floor window; no one in his senses would do it unless the stairs were on fire. But in post war Britain the stairs have always been on fire (Taylor 1993, 247).

Pay policies, even those generally deemed to be successful affected some organisations more than others. Unfortunately for monthly paid staff at the BBC, just prior to the 1975 Social Contract (the main plank of which was a voluntary pay policy), their weekly paid colleagues had received a $20 \%$ increase, and management were then unable to make up the difference by making a similar award to them. By mid-1976, a comparative study showed that the BBC was at or near the bottom of scales of employers for the first time in twenty years. The Director of Engineering, J Redmond, told the General Advisory Council that July that over $60 \%$ of successful candidates for jobs were turning them down. They had been forced to put off retirements and to re-engage some retired staff. Staff, especially experienced programme makers were being lost to ITV (which had awarded $20 \%$ to all staff just prior to the pay policy) leaving a gap in future prospects for management from whose ranks they would be drawn. Young technicians were going too (R78/1,680/1 Finance BBC 1975-79 J Redmond DE General Advisory Council 20/7/76, BBC WAC). The pay policy was in theory voluntary, although in the case of the BBC, wrote a senior manager the following year, they well knew what the government's response would be if they broke it. They had just been awarded for the first time ever, a licence fee settlement for one year only, "By limiting the BBC's income in this way", he went on, "the government, has the tightest possible hold it could wish 
on the BBC"s pay negotiations" (R78/209/1 Finance BBC 1970-75 27/10/77 Memo MO Tinniswood D Personnel to lan Trethowan DG, BBCWAC)." The BBC, like other public bodies, was unable to determine itself, or through negotiation with its workforce, what it thought were appropriate rates of pay. For the staff, what they could not get in the annual negotiating round on basic pay, they were able, depending on where in the production chain they worked and how well organised they were, to obtain by other means, and a significant number of disputes, whether over payments for expenses, rostering agreements, claims for re-grading, or payments for working overtime, were the result of compromises made and deals done in the mid-1970s, in efforts to get round pay policies.

Broadcasting had stopped being a craft and was now an industry and this industrialisation of the process of making programmes led to its own problems. BBC Television Centre had become a large factory, with hundreds of shops and departments and a workforce of thousands, divided along craft and occupational lines, and the dynamics, which applied outside in industry, were increasingly felt within. The working day became routinised, and with the routine and the scale of operations, came a new-found alienation - from the work itself and one set of workers from another. What was most shocking about the 1969 walkouts, was that in the case of, for example the studio crew working with Yvonne Littlewood, they were permanently assigned to her, so there was, or had been, a close personal as well as professional relationship between them. People were proud to work for the BBC. "The BBC had cultivated that, the BBC family notion from the very beginning". It was now beginning to wear thin, especially in Television Centre, where, because of its size, different sets of workers were housed separately. They were organised separately as well, the ABS alone having at one time eight branches there. All this led to a degree of fragmentation" (Hearn interview).

That some union members through the use of whatever industrial power they possessed, were able to gain advantage for themselves was not to the liking of the $A B S$, which represented people across the entire organisation. The ABS widely regarded as "a somewhat tame union run by its head office", was seen by some to be unhealthily close to BBC management (Brooks 1984). Tony Hearn recalled,

We were embedded into the BBC in a very intimate way, apart from anything else, in much of my period, very senior managers had been ABS members at one time because in those days the BBC got its managers from its own ranks.

Though people changed their views when they got a new job "by the same token not every loyalty dies". For their part, the ABS was "quite shamelessly pro BBC", and when it gave evidence to the perennial committees of enquiry into broadcasting, "the BBC could've written it almost" (Hearn, interview). In 1976, in a striking example of how the views of management and union leadership could coincide, a working group set up the previous year reported on the subject of "Pay, Structures and Conditions of Service". As a description of the current situation, they said, they could not find better than the following from an ABS policy document, written by Tony Hearn:

Intolerable pressures have been placed on the grading system. Instead of being used as a device for settling internal relativities, it has become, at a time of incomes restraint and quickening technological change, a free-for-all [...] Men seek through the internal grading system to restore what they believe to be their proper pay levels as judged by external comparisons. In so far as they are successful, however, they distort the pattern of internal relativities and bring about a situation in which powerfully-organised groups appear to be using the union to secure for themselves short term sectional gains at the expense of the less well-organised or more moderate majority (R78/2016/1 part $3 \mathrm{BM}(76) 71$ "Pay, Structures and Conditions of Service D. Pers.'s Working Group Report, BBCWAC).

Employers and employees both sought to find ways round government restrictions. A new cottage industry grew up, of consultancy firms offering advice to companies on methods of 
providing hidden increases. A more commonplace approach was the mechanism of regrading, and as the 1970s progressed, disputes connected with re-grading increased. Management often had some sympathy with those making claims, even in 1977, in the face of the kind of guerrilla action by then standard - soutside broadcast cameramen selectively setting up and then walking out, causing the loss of high-profile programmes like $A$ Song For Europe, and the Eurovision Song Contest - a board meeting was told that people were hard up and had no alternative (Board of Management, 24/1/77 $46 \mathrm{~J}$ Redmond, the Director of Engineering, BBCWAC, hereafter BOM). The Director of Personnel, Michael Bett, told board of management in May 1979 that the department responsible had dealt with 456 grading claims in 1972, but that for the previous year, (with, he added only one additional staff member), they had processed 872 . Nearly all, had been instigated by management - evidence DG lan Trethowan said "of their attempts to circumvent the incomes policy (BOM 14/5/79 365, BBCWAC)". This was a practice of which politicians were of course fully aware, and just prior to this, shortly before the election which brought Mrs. Thatcher to power, the Labour government let it be known that they regarded a re-grading settlement just achieved as breaking their guidelines. The BBC would need a good case, Trethowan warned his colleagues, to present to Labour if they were re-elected. On the other hand, if the Conservatives won, "they could be expected to be cheerful about the re-grading and equally cheerful about saying the BBC could not have more money to pay for it (BOM 23/4/79 315 (c), BBCWAC)".

National agreements, especially in large organisations such as the BBC, often broke down at a local level and a series of layers of local interpretations, agreements, and practices grew up over time. Each time a concession was made in one area, comparisons, were made by workers elsewhere, causing constant turmoil (Crouch 1978, 206). This was the case across industry: one 1980 study compared labour relations in one British and one German tyre plant, owned by the same company. The German plant had never had a stoppage whereas the British factory was plagued by them. In the British plant, pay was established at a shop floor level by local agreements, each decision having a knock on effect, creating an anarchic system of continually arising anomalies to be sorted out, which themselves engendered further anomalies. Relativities were key points of dispute. "Not surprisingly, then, the British factory's pay structure represented the deposit of literally hundreds of separate trials of strength between groups of workers and management" (Maitland 1980, 357-359).

Hearn continued to lambast the BBC hierarchy for what he saw as its complicity in the ongoing strife. But accusations went both ways; forced to defend the actions of his union at a BBC management conference early in 1980, he conceded, (somewhat grudgingly) "If unions were villains, they were only little villains because they reacted to circumstances" (R1/116/5 G49/80-G60/80 BOG Papers 1980 G57/80 Uplands Management Conference18-29/2/80 4 (b) T Hearn ABS, BBCWAC). He returned to the attack in the midst of considerable industrial unrest two years later: in the midst of disputes with the NUJ, the ACTT, various branches of the ABS over pay, grading, recognition and the use of new technology; and an inter-union wrangle between the ABS and the electrician's union, the EETPU. The blame for all, he laid at changes to pay relativities the management had introduced some two years previously, in 1980. Following the settlements achieved by the ITV unions after their all-out strike in 1979, in order to stem the flow of expensively-trained technicians to the commercial companies the BBC had awarded staff in the affected areas large pay awards. This had led to further claims for re-grading and by 1982 the corporation was in turmoil. Present pay structures were not ordered or evaluated he wrote but were "a crude reflection of internal pressures and market forces". He went on that DG Alistair Milne had recently cast them as the villains of the piece, in keeping with current government policy, but "If there is anarchy in the BBC"s industrial relations at present, and there is, it is anarchy of the BBC"s own making" (BBC Management Registry, Industrial Relations-Association of Broadcasting Staff Part2 01/04/72-31/3/90 Open letter T Hearn 6/10/82, BBCWAC). 


\section{Scenic Services: Industrial Muscle, Overtime and Local Agreements}

All of the above factors were at play in the scenic services department in 1984. The workers, previously NATTKE members who were just becoming members of the ABS, were in manual grades, carpenters, painters and labourers, who constructed, painted and moved the scenery in Television Centre. At one of the pinch points in the system, close to the camera, they had real industrial muscle, and theirs was one of the areas in which local agreements had developed over time. Industrial action in the studios could affect not only current but future programmes as they were in constant use and any delays would upset the schedule of rehearsals and filming. NATTKE was a much less centralized union than the ABS and powerful shop stewards had been able to exact very favourable conditions for themselves, in working practices, manning levels and overtime payments. Working large amounts of overtime, a distinctively British practice (Crouch 1990, 335), has always, by the nature of the industry, been a feature both at the BBC and at ITV. Technicians in particular, worked large amounts of overtime; in 1977, some worked more than four hundred hours in overtime per annum and almost half of these over eight hundred hours (R78/2016/1 Conditions of Service Policy Non-manual staff part 3 Memo 10/10/77 A Milne to lan Trethowan, BBCWAC). The following year, some of the weekly paid staff, scenery carpenters and painters were earning the equivalent of twenty five hours per week throughout the year in this way (R78/2016/1 Conditions of Service Policy Non-manual staff part 3 memo CDP Kinchin Smith 3/5/78, BBC WAC). On overmanning, an internal working party into scenic operations reported that "there is considerable over-manning, arising either from agreements with the Unions, from established custom and practice, or from poor managerial control and even deliberate managerial connivance". The end result of this state of affairs it concluded was "poor service to productions, high costs and a continuing sense of desperate frustration elsewhere in the service".

At the time of the ITV strike in 1979, one of the board showed his fellow managers a newspaper article full of the arcane practices, "old Irish customs", plaguing ITV (Junor 1979). The Director of Personnel, Michael Bett, warned his colleagues against complacency on their part, for they were not "Simon pure" either and, furthermore, "the staff concerned knew that there were abuses which made them laugh when the BBC boasted of its efficiency in public" (BOM 29/10/79 711g, BBCWAC). But what was needed to tackle these issues was a philosophical change in management. It was to take the financial exigencies of the late 1970 s as a spur, a reassessment of priorities and a reorganisation of management as the preconditions, before the BBC could finally countenance confrontation with the growing assertiveness of the workforce. For if the ABS leadership protested at the "anarchy" inherent in the system, sections of their membership, and of the other broadcasting unions including the largely NATTKE members in the scenery block at Television Centre, had learned the lesson of October 1969, and, subsequently, hampered as they were by the lack of a closed shop, had nevertheless set out to apply pressure wherever and whenever it was possible.

\section{Five Men's Work for Four Men's Money: Structure and Pressure}

For more than a decade, in the face of union pressure, "the whole philosophy of the BBC had been the show must go on, which meant that at every point the show must go on". As in the case of the ITV companies, this left management, particularly those charged with responsibility for resources, powerless. "At the end of the day, you do the show [...] Once you'd got that philosophy, the show goes on, you're stuck as a manager, you can't negotiate" (Michael Checkland, Director of Resources BBC Television seminar, University of Westminster 2003). With programme makers and programme-making in the ascendant, other considerations were less important. Short-term exigency dominated over long term planning. The size and duration of the licence fee settlements in the late 1970s was to change this. As the financial situation became more difficult, costs became ever more crucial. As a consequence, the management of resources became uppermost in the minds of those at the top, and what had been considered as ancillary to programme-making became central.

There were political as well as economic reasons for this. In the climate of the time, the $\mathrm{BBC}$ was included in the list of those organisations; nationalised industries, local government 
and the like, which were home to all the cardinal vices of bureaucracy, wastefulness, restrictive practices, (plus a few more of its own) which the Conservatives were going to eradicate and the BBC had to demonstrate its willingness to act. It may also have felt emboldened to do so. A new willingness to confront the unions began to manifest itself. In September 1980 a serious clash occurred in the scenery department, over internal demarcations. Negotiations failed and the workforce went on strike. No scenery was being moved and management suspended all of those involved, some 400 personnel in total. Eventually a "face-saving formula" was found and all were reinstated, but the management made no concessions and saw the resulting publicity as reflecting well upon them, "in public" the Director of Public Affairs told his colleagues, "the BBC was seen to be resisting over-manning" (BOM 22/9/80 505 DJ Webster, Director of Public Affairs, BBCWAC). New imperatives meant a new structure was necessary and in 1982 the BBC created the post of Director of Resources, with a seat on the board, to sit alongside the Director of Programmes. The first incumbent was Michael Checkland, who was eventually to become Director General. His appointment was considered in the press as "a signal to intensify the struggle against inefficiency and over-manning, which has bedeviled public service broadcasting" (Wilimott 1984).

Part of the new resource structure was the appointment of general managers, in different areas, one of them being Design and Scenic Services. All reported directly to Checkland, and they therefore now had support up to board level, something their predecessors could never count on. In scenic services, any previous reluctance at tackling the unions head on was fast disappearing. A pattern was set, with demands from the workforce, to be met with management refusal, secure in the knowledge that they had backing higher up the structure, then action by staff, who were then suspended, only to be reinstated after the dispute was settled. Against this background of hugely damaging skirmishing, management and unions engaged in talks for three years on new conditions of service for the scenery department. A new attitude towards productivity was articulated by the director of personnel Christopher Martin in 1984. It was difficult for the BBC to measure productivity because of the peculiarities of the broadcasting industry but Martin summed up the objective as a ratio 3:5:4; "three men doing five men's work and getting four men's money" i.e. a smaller, better paid and more productive workforce. In outlining this new aspiration, he questioned whether they as a management had the "attitudes and skills to pursue aggressively" a high productivity policy or "had staff policies traditionally been more concerned with fairness and equity than with efficiency (D71/D72-4 (4) BOG/BOM Conference 1984 Part 4, BBCWAC).

In scenic services, what the management wanted was to reduce staff numbers, reduce the amount of extra payments in take-home pay and to reduce the number of categories of workers. They also wished to eliminate a series of agreements over working practices, which were eventually to total fifty-seven in number. The hope was to eliminate over 150 jobs and save $£ 1.5 \mathrm{~m}$ out of a total budget of $£ 8 \mathrm{~m}$. In return they were to increase basic pay by up to $17.5 \%$, financed by the loss of posts and the reduction in overtime. By the autumn of 1983, negotiations were not going smoothly and the staff was operating an overtime ban, in contravention, so wrote the general manager Duncan Thomas in an open letter, of assurances given to ACAS by the two unions" leadership. Re-organisation, he threatened, would in this context take place earlier rather than later. On the same day he warned his fellow managers to expect disruption, particularly as, in anticipation of the re-organisation and consequent redundancies, they had "allowed a number of vacancies to arise following resignations, retirements, etc (RAPIC A1218 Scenic Operations General Oct 1983-Jan 1984 File 4 Duncan Thomas Letters, BBC29/11/83, BBCWAC). The fifty-seven agreements, the BBC put to the union side in a series of meetings in December and January. On February $1^{\text {st }} 1984$, having failed to reach agreement, NATTKE invoked arbitration. This, the BBC refused and indicated they intended imposing the new conditions from February 18th. The unions threatened industrial action and the scene was set for a confrontation. 


\section{Nineteen Eighty Four}

1984 was a year of confrontations, most famously between the government and the National Union of Mineworkers. At the BBC, too, there was trouble in abundance, some industrial, some political; all adding to an atmosphere of crisis. A Panorama programme on supposed right-wing infiltration of the Conservative party, Maggie's Militant Tendency, broadcast on January $30^{\text {th }}$, led to numerous lawsuits and thrust the corporation into a very unwelcome and damaging political dispute with government. The printing interests of broadcaster David Dimbleby, brought him into a dispute with the National Union of Journalists, who threatened to black programmes such as the Budget in March if he appeared. In addition were problems, originating the previous November, with one of the print unions, SOGAT 82, over production of the Radio Times, in the course of which, the BBC and publisher Robert Maxwell had obtained an injunction against the union restraining them from preventing distribution of the magazine. At Board, senior management was very unhappy at the conduct of this dispute, feeling they had been "railroaded" by Maxwell into legal action. Having secured their agreement, he had then promptly hidden behind the BBC, leading, as ADG Alan Protheroe told his colleagues the following week, to "a public perception that the BBC itself was initiating the action against SOGAT and that Maxwell was a reluctant follower", and urged his colleagues to sever their "compromising" connection with Maxwell, and find another printer.

BBC management was concerned about the effect of this affair on relations with other unions - and that if SOGAT 82's funds were sequestered, they would be blamed and unable in future to engage any unionised firm to print for them (BOM 16/1/84 19; 23/1/84 37, BBC WAC). "The balance of advantage", Protheroe had advised, "was to avoid union bashing." And the unions did indeed accuse the BBC of doing just that - dusing the new anti-union legislation more than any other organisation, in the Dimbleby affair and over the Radio Times (Goodhart 23/3/1984). John Foster of the NUJ, linked both cases in a letter to the Guardian saying of the decision to use Dimbleby for their budget programme, "Perhaps it's just part of their new macho policy towards all BBC unions or else penance to the government over Panorama" (Foster 1984). Management tried to dig their way out of the Radio Times hole by disassociating themselves from the injunction, but the fond attentions of "Captain Bob" Maxwell were not so easily spurned, and when the BBC suspended his contract and employed another firm, amidst fears that SOGAT would black them too, and thus land the corporation in the quagmire of sequestration in any case, the litigant par excellence threatened the BBC with legal action. They caved in and reluctantly agreed to honour his contract, feeling that his record "was not a pretty one" (BOM 6/2/84 78, BBCWAC). If the BBC was bashing the unions, the bloodletting was not all one-sided; a long-running dispute with the NUJ over payments for the use of new technology, Electronic News Gathering (ENG) had escalated dramatically on January $12^{\text {th }}$, when the union had called a mandatory meeting at $8.30 \mathrm{pm}$. The nine o'clock news, for the first time in the corporation's history had not gone out, which "was seen by management and by unions at the BBC as an important symbol" (Goodhart 1984).

The BBC, the ABS and NATTKE had been in discussions for two years prior to Christmas 1983. Lengthy negotiations such as this were common at the BBC, where there were "immensely complex and civilised", procedures, involving 146 separate liaison committees between management and unions. In an organisation where there were more than 80 different craft and professional groups working together, head of personnel Christopher Martin said at the time that they could not be heavy handed (Goodhart 1984). In a creative organisation, above all else, the team had to work. Teamwork and relationships were crucial. People couldn't work if they were unhappy. This informed attitudes to industrial action, said Roger Chase, Martin's deputy at the time and eventual successor, "You don't break strikes, what you do is seek to get people back to work on terms which are acceptable all round and renew the relationships which were there beforehand". This concern with good relationships was particularly important to them, because of the way in which programmes have to be made. "There aren't too many organisations which have this need from the top to the bottom" (Roger Chase seminar, University of Westminster, 16/10/03). 
To the ABS, management's newfound willingness to confront them was unwelcome but not entirely surprising. "There"s no doubt [...] because I thought so at the time, that we overplayed our hand in some of those disputes in the 70s [... ]we pushed the BBC too far". This was not a view, of course to which all the members or even officials would have subscribed.

I used to try and convince our executive of that but keeping the militants, in inverted commas in check was very difficult [...] So you see there were these tensions within the union. We had to give a bit and we couldn't keep a curb on the television branches as much as we might have. All things being equal and that meant we were being dragged by the television branches into disputes that the BBC obviously didn't want us to win (Hearn Interview).

The scenic services dispute was one the management was determined to have their way. The changes in management had been made precisely to address these questions. The unions, on the other hand, were obliged to fight at a time when both the outside political climate was getting distinctly chilly for them, and when they were far from convinced of their own case. Sometimes unions lead and at others they are led: "everybody knew the BBC were overstaffed [in this area], but our members were clear they wanted to fight for their jobs. They were some of the better paying jobs" (Gerry Morrisey, BECTU interview 19/5/2003). They were not going to give up what they had won over the years without a fight. In addition, the fledgling ETA, born in February that year from the ABS and NATTKE, did not want to begin life with a defeat. Defeat, was what faced them, however, and the course of the dispute was about how to manage and present it.

The day after they had invoked arbitration, February 2nd 1984, the ABS and NATTKE leaders told the BBC that they believed that eventually the BBC would have its way. If the corporation agreed to arbitration, management would achieve its aims without industrial action, if the BBC did not agree, the members would strike and they would be obliged to support them. Management refused, seeing arbitration as a cynical use of the procedures, designed provide a cover for the two general secretaries, which would allow them to "wash their hands of the outcome", which suited them. It would also inevitably involve a lengthy delay, when they felt they had delayed enough already (RAPIC A1218 Scenic Construction/Scenic Re-Organisation Feb 1984-April 1984 File 5 Memo PF Donnelly to M Checkland 3/2/84, BBC WAC).

On February $18^{\text {th }}$, the management imposed the new conditions of service and the staff walked out. The ABS (ETA) characterised it as stemming from "the neo right-of-themanagement-to-manage school of thought" (RAPIC A2848 Dispute Scenic Construction/Operations Reorganisation Jan 1984-30/6/1993, BBCWAC. Tony Hearn ETA notice $24 / 2 / 84$, BBCWAC). The BBC board was told after the first two days that "only a couple of dozen staff out of a total of 400 were working." The strategy was to try to keep live programmes going, but inevitably there would be losses to recorded programmes. Checkland reminded his management colleagues what was at stake, "a reduction of 166 posts, and a potential saving of $£ 11 / 2$ million". The following week it was noted the strike had been made official, there were 520 staff on strike and that no scenery from outside was being brought in (BOM 20/2/84 109; 27/2/84, BBCWAC). As the dispute dragged on into March, management, though it would not compromise on the main aspects of its re-organisation plans, sought to find areas where they would be prepared to go to arbitration, and had upped their pay offer to $20 \%$. They felt that although the union leaders were willing, that in turn they "were apprehensive about the influence of some particularly active shop stewards". After consultation, the unions said they would arbitrate on all or nothing (BOM 19/3/84 180; 26/3/84 BBCWAC). The BBC then escalated the dispute; Bill Cotton, the newly appointed Managing Director sent out letters warning staff they were in breach of their contracts of employment and faced dismissal.

A week later, all 600 of those involved were sacked, asked to return their identity and (powerfully symbolic for BBC staff) their BBC Club membership cards. The union response to this was to call on the rest of the staff to support the strikers. This, they had not done so far, 
Hearn was reported as saying, because they did not want to antagonise the public. Significantly, the other reason he gave for his reluctance to spread the dispute was because of the costs involved. The merged union, which was paying its members strike pay of $£ 30$ per week, had spent up until the end of March $£ 100,000$ out of joint funds of $£ 600,000$. "We relied on the lightning walkout, until it was outlawed, stoppages of the length that they had in ITV, were simply impossible in the BBC", as the union could simply not afford it. NATTKE was, at the time of the amalgamation with the ABS, "close to bankruptcy". Its financial problems were caused in part by the difficulty of organising labour in the film industry, where "everyone belonged to the union but no one paid their dues". The guerrilla tactics favoured by the BBC unions, the lightning strikes, the selective action in limited areas, were an imaginative response to their fundamental overall weakness. They were, said Tony Hearn, "concentrated in key areas, that was their strength". However, "What always struck me was that if the BBC had ever decided that it had had enough and was prepared to suffer the loss of a few day's programmes, it could beat us hands down" (Hearn interview).

That was precisely what BBC management intended to do. A senior figure had been quoted in the press as saying, "Keeping programmes on the air at any price is no longer the first priority" (Goodhart 1984), and when on April the $4^{\text {th }}$, in response to the sacking of the 600 scenery workers, 2,000 staff at Television Centre walked out, BBC management did not attempt to cover for them but allowed the screens to go black. BBC1 was off the air for 24 hours.

\section{The Rubicon Crossed}

This was a signal that times had changed, that the corporation was moving into new territory. The message appeared to get through; on the $9^{\text {th }}$, both sides met at ACAS and after two days of discussions, the unions recommended acceptance of almost all of the management's demands, in return for an increased pay rise of up to $20 \%$ and arbitration in one limited area. The staff reluctantly agreed. Hearn tried to put the best face on it, he told the press the men could go back "with their heads held high" (Knight 1984), but it was a defeat. In the meantime, as the BBC scenery staff returned to work in an atmosphere of tension and bitterness, which was to last months, over at an ITV flush with advertising cash, the ACTT had just won "golden time"; 3 times the normal rate, for extended periods of overtime on making commercials (Barker 1984).

The balance of power had shifted, and the initiative returned once more to management. It was not merely a question of victors and vanquished though. Both management and unions recognized that the brinkmanship of the recent past would have to be set aside, and there existed "a joint understanding of what the problems were and a joint willingness to do something about them", and partly in response to a letter from Hearn to BBC management in February, a review of industrial relations at the BBC was carried out, and renewed emphasis placed on professionalism in negotiations and the willingness to explain decisions in order to carry the workforce" (Chase, seminar, University of Westminster, 16/6/03)

\section{Conclusion}

How events are viewed by posterity (at least in the popular mind) is determined to an extent by how they were described at the time. If this very "Thatcherite" dispute was seen by unions and management at the BBC as being symbolic of the new conditions, how, we can ask did it play outside, in the press and in the world of politics? Reporting was slow at first, the press being taken up with generalised criticisms of the BBC: in the Evening Standard for being run by unimaginative bureaucrats; in the Economist for chasing ratings and being down market; and in the Spectator for being too big, incorrigibly snobbish, anti-market and anti-British (Hastings 1984, Johnson 1984, Anonymous 1984). After the men went on strike, the newspapers took more interest, as both sides sought to use the media to get their point of view across. Ultimately though, if the BBC had thought it would get credit for standing up to the unions in the way managements were being urged to do, it was to be disappointed. 
A column in the right wing Daily Express referred to the dispute and the fact that BBC was trying to reduce staff numbers but instead of offering support and encouragement, as one might expect, criticised the BBC for the usual sins of being too big and too bureaucratic, and went on,

The BBC has over 700 scene-shifters. What on earth are the scenes these shifters are forever shifting around? By the BBC"s own reckoning, it could do without 189 of them. It has been having an industrial dispute on the matter (Gale 1984)

It went on to call for the break-up of the corporation. After the strike ended, Conservative MP Christopher Chope wrote to DG Alasdair Milne, complaining that the $20 \%$ pay settlement was excessive, but saying nothing about the redundancies (RAPIC A1218 Scenic Construction/ Scenic Re-Organisation Feb 1984-April 1984 File 5 letter C Chope to A Milne 30/4/84, BBCWAC) and when the BBC asked for a licence fee of $£ 65$ that December, the Times complained about rising levels of staffing, the Daily Mail about BBC management failing to control "spiralling costs" and the Daily Express, not letting the fact that he had been dead for over twenty five years get in the way of a telling phrase, said in a front page opinion column that the BBC "now has more scene shifters than Cecil B De Mille" (Havilland and Hewson 1984, Hughes and Adams 1984, Anonymous 1984)

The "first draft of history" clearly missed the point. The ground at Television Centre, (as in industry generally), had shifted fundamentally. The unions, increasingly hampered by legislation, which sought to limit their ability to act, were now on the back foot. For them this was to herald a period of retrenchment, redundancies, shrinking membership. Management at BBC, after a decade of acquiescence in the face of union militancy, was finally emboldened to meet it head on but it should be remembered that it had been a militancy almost as unwelcome to the unions as to BBC management.

\section{References}

Anonymous.1984. What is the BBC For? Economist, February $18,7$. Anonymous leader. 1984. Say No to the BBC. Daily Express, December 13, 1.

Barker, Dennis. 1984. Golden Deal on TV Overtime. Guardian, April 27, 9.

Brooks, Richard. 1984. Hopes Brighten for Talks to End the BBC Scenery Strike. Sunday Times, August 6, 3 .

Burns, Tom. 1977. The BBC: Public Institution and Private World. London: Macmillan Press.

Campbell, Al. 2005. The Birth of Neoliberalism in the United States. In Neoliberalism: A Critical Reader, edited by Alfredo Saad-Filho and Deborah Johnston, 187-198. London: Pluto Press.

Campling, John T and Grant Michelson. 1997. Trade Union Mergers in British and Australian Broadcasting, British Journal of Industrial Relations 35 (2): 217-222.

Carr, Edward H. 1990. What is History? London: Penguin.

Collingwood, Robin G. 1994 The Idea of History. Oxford: Oxford University Press.

Crouch, Colin. 1978. The intensification of Industrial Conflict in the United Kingdom. In The Resurgence of Class Conflict in Western Europe Since 1968, edited by Colin Crouch and Alessandro Pizzorno, 191-256. London: Macmillan Press.

Crouch, Colin. 1990. United Kingdom: The Rejection of Compromise. In European Industrial Relations: The Challenge of Flexibility, edited by Guido Baglioni \& Colin Crouch, 326-338. London: Sage.

Curran, James. 2002. Media and Power. London: Routledge.

Duménil, Gérard and Dominique Lévy. 2005 The Neoliberal (Counter-) Revolution. In Neoliberalism: A Critical Reader, edited by Alfredo Saad-Filho and Deborah Johnston, 9-20. London: Pluto Press.

Evans, Eric J. 2004. Thatcher and Thatcherism. London: Routledge.

Gale, George. 1984. Throw Away your Begging Bowl, Auntie. Daily Express, February 24, 9.

Garnham, Nicholas. 2000. Emancipation, the Media and Modernity: Arguments about the Media and Social Theory. Oxford: Oxford University Press.

Goodhart, David. 1984. BBC Puts on a Show of Strength. Financial Times, March 23, 6.

Hastings, Max. 1984. Why the Likely Lads Get Out. Evening Standard, February 2, 7. 
Haviland, Julia and David Hewson. 1984. Thatcher Favours Some Ads on BBC. Times, December 13, 1.

Hughes, David and Adams, Jane. 1984. Advertising on BBC? Daily Mail, December 13, 2.

Johnson, Paul. 1984. Clattering BBC Train. Spectator, February 18, 5.

Junor, Roderick. 1979. Another Licence to Print Money. Daily Telegraph. October 26, 13

Kaufman, Bruce E. 2008. The Original Industrial Relations Paradigm: Foundation for Revitalizing the Field. In New Directions in the Study of Work and Employment: Revitalizing Industrial Relations as an Academic Enterprise, edited by Charles J. Whalen, 31-47. Cheltenham: Edward Elgar.

Knight, P. 1984. BBC Strike Ends after 20pc Offer. DailyTelegraph. April 16, 2.

Last, Richard. 1979. Behind the Blank Screen. Daily Telegraph, October 1, 13.

Lyddon, Dave. 1999. "Glorious Summer", 1972: The High Tide of Rank and File Militancy. In British Trade Unions and Industrial Politics: The High Tide of Trade Unionism, 1964-79, edited by John Mcllroy, Nina Fishman and Alan Campbell, 326-352. Aldershot: Ashgate.

Maitland, lan. 1980. Disorder in the British Workplace. British Journal of Industrial Relations 18 (3): 353-364.

Saad-Filho, Alfredo and Deborah Johnston, eds. 2005. Neoliberalism: A Critical Reader. London: Pluto Press.

Seglow, Peter. 1978. Trade Unionism in Television. Hampshire: Saxon House.

Taylor, Richard. 1993. The Trade Union Question in British Politics: Government and Unions Since 1945. Oxford: Blackwell.

Tosh, John. 2002. The Pursuit of History. London: Longman

Travis, Alan. 2013. National Archives: Margaret Thatcher Wanted to Crush Power of Trade Unions. Guardian, August 1.

Undy, Roger. 1999. The British Merger Movement: The Importance of the Aggressive Unions. Industrial Relations Journal 30 (5): 464-481.

Willmott, Nigel. 1984. Changes Certain but Old Guard Holds On. Television Weekly. February 24, 7.

Wrigley, Chris. 1997. British Trade Unions 1945-1995. Manchester: Manchester University Press.

\section{About the Author}

Dr Anthony McNicholas

Is a media historian in the Communication and Media Research Institute of the University of Westminster, where he is Director of the $\mathrm{PhD}$ programme. His research interests are nineteenth century Irish journalism and British broadcasting and the media and politics generally. He was previously chief researcher on an AHRC funded project to produce volume 6 of the official history of the BBC, covering the years 1975-87, to be published shortly by Profile Books. 